\title{
CLUB ACTIVITY IN THE EARLY PHASES OF MICROCOMPUTING IN FINLAND
}

\author{
Petri Saarikoski \\ Lecturer, Digital Culture, Degree Programme in Cultural Production and Landscape Studies, \\ Unviersity of Turku, Siltapuistokatu 2, PL 124, 28101 Pori. Formerly Researcher, Deparment \\ of History,University of Turku; petsaari@utu.fi
}

Abstract: History has ignored several aspects concerning the early phases of Finland's computerization activities. This article concentrates on the early history of microcomputing in Finland, in the light of three computer clubs. An interactive relationship between paid work and private hobbies was typical in the early phases of microcomputing. The educational and do-it-yourself aspects of about computers enhanced learning.

Key words: History of microcomputing, computer hobby, computer clubs, Finland

\section{INTRODUCTION}

Research on the history of Finnish information technology is still in its early stages. There is remarkable little research available on the early history of microcomputing in the 1970s. In some memoirs, there has been a tendency to underline the importance of computer hobbyists as pioneers and actors of personal computing. ${ }^{\prime}$ In other countries, especially in the United States, long traditions in this research field already existed. Some writers, for example Steven Levy, have described computer hobbyists or computer hackers as dedicated and idealistic technological crusaders. Levy has

1 For example, Mikrojen 20 vuotta ("The First 20 Years of Microcomputers") in Mikrotietokone Suomessa 1973-1993 ("Microcomputers in Finland 1973-1993"), Risto Linturi, Martti Tala (eds.). Helsinki 1993. 
pointed out that the early users of microcomputers were actually users of the first PCs and they created a PC culture in societies of their own. ${ }^{2}$

In my research work, I have concentrated on the history of the home computer culture in Finland from the 1980s to the 1990s. ${ }^{3}$ Jörgen Nissen and Tove Håpnes have also examined this phenomenon in the Nordic region. ${ }^{4}$ In this paper, I will concentrate on the early microcomputing during the 1970s and the 1980s. I will explore certain important social and cultural aspects of early personal computing. How important was the role of computer hobbyists in the development of microcomputing? What kind of new activities did early microcomputing provide? What was the interaction between work and hobby? We approach these questions by studying the activity of three computer clubs: The 1800 Users' Club Association, the Mikrofan-Computer Club Association of Pirkanmaa, and the Microprosessor Club of Salora Ltd. There are still only few detailed studies available in Finland on the history of computer clubs. ${ }^{5}$ The lack of documented historical research on the early stages of microcomputer clubs presents a need for basic research.

\section{THE MICROPROCESSOR AND FINLAND: THE EARLY STAGES OF THE $1970 \mathrm{~S}$}

In research on the history of computing, we generally regard the invention of microprocessor as the beginning of "microcomputer revolution". The development of microprocessors was still only a small albeit important - turning point in the history of computing industry. The most important feature was the technical advancement in the semiconductor industry. The development of integrated circuits, semiconductor memory, and other inventions resulted computers were more effective although their physical size was reduced. Historians of information technology have usually called this technical progress the "Revolution in Miniature". One of

2 Levy 1994.

3 Pioneerien leluista kulutuselektroniikaksi. Suomalainen kotimikroharrastus tietotekniikan murroksessa 1980-luvun alusta 1990-luvun puoliväliin. ("From the Toys of Pioneers to Consumer Electronics. The Cultural History of Home Computing as Hobby in Finland from the 1980s to 1990s."). Turku 2001.

4 Håpnes 1996, Nissen 1993.

5 This article is an updated version of article published in Tekniikan Waiheita, periodical published by Finnish Society for the History of Technology. Saarikoski 2002. The doctoral thesis of Jörgen Nissen provides further insight into this field within the Nordic countries. Nissen 1993. 
the major features of this "revolution" was the development of minicomputers. ${ }^{6}$

Researchers have usually emphasised the importance of the social activity of young students who used minicomputers as personal working stations. In Finland, the sales of mainframe and minicomputers increased during the 1960s. According to some sources, there were some 210 mainframe computers and about 700 minicomputers in the spring of $1971 .^{7}$ The teaching of data processing began in the Finnish universities during the 1960s, and some basic courses were available in some schools and institutes in late 1960 s and early 1970 s. The very first courses were probably those offered in Tapiola co-educational school in 1965, arranged by IBM Finland and Helsinki University of Technology. ${ }^{8}$

In the late 1960s, the construction plans for personal computers appeared in special interest magazines. ${ }^{9}$ The availability of cheap and advantageous microcomponents increased in the beginning of the 1970s. The culmination of this process was the introduction of first microprocessors in 1971-1972. ${ }^{10}$ After this point, the mass production of microcomputers was technically possible although not profitable. The Altair 8800 (introduced in the spring the 1975) is often mentioned as the first successful microcomputer. The computer hobbyists mainly used the Altair, which was a kit computer. ${ }^{11}$

Finnish computer experts and professionals were fully aware of the importance of microprocessor industry. When the first microprocessors were introduced, Finnish research and development (R\&D) work began almost immediately. For example, the import of Intel 8008 -type microprocessor began already in 1973. In Finland, early adopters of microcomputing had already some experience, particularly of electronic circuits, kits, and electronic hobbies. Some of the enthusiasts were already professionals or students of data processing. Professionals and/or students of information technology who started their activities in 1973-1974 conducted the first microcomputer clubs. ${ }^{12}$

Finland imported microcomputers almost as soon as they were available in Europe. Although memoirs and surveys have often mentioned that microcomputers that were popular in the United States, for example Texas

Campbell-Kelly, Aspray 1996, 222-226, 240-241, Ceruzzi 2000, 182-189, 207-211. Jaakko Suominen has concluded that in Finland the term "miniature" was already in use during the 1960s. Suominen 2000, 167, 305. Jokela, Korkala, Sarso 1972 chapter 1. pages 6-10.

8 Tietokonekerho Tapiolassa, IBM Katsaus 2/1965, 20, Pantzar 2000, 84.

9 Wiio 1993, 152.

10 Ceruzzi 2000, 211-224, Campbell-Kelly, Aspray 1996, 236-237.

11 Freiberger-Swaine 2000, 43, Campbell-Kelly, Aspray 1996, 240-244. For the reception of Altair kit computer among the computer hobbyists, see Levy 1994, 191-197.

12 Bell, Linturi, Tala 1993, 9-10. 
Instruments, Imsai, and TSR-80 did not sell very well in Finland. Interestingly several important computer models were not even imported to the country. High customs duty was one of the main reasons for this. During the period 1975-1980, serial produced microcomputers were considered particularly expensive tools for computer professionals. According to some sources, in Finland the Commodore PET and the Apple II were the best-known serial produced microcomputers in the late 1970s. ${ }^{13}$

To conclude, the above factors resulted in the long-term popularity of kit computers in Finland. However, in the early stages, the availability of kit computers was limited. Some of the importers of microprocessors provided only "evaluation kit" -type assembly kits that contained a hexadecimal keyboard, LED display, and primitive operating system. Between 1974 and 1977 , there was virtually no company providing domestic kit computers for the Finnish market. When Telmac 1800 was introduced in October 1977, the shortage of equipment supply was partly relieved. This kit computer was designed by Osmo Kainulainen and it was based on the RCA Cosmac CDP 1802 -microprocessor. Osmo Kainulainen has mentioned that they invented the Telmac after some professional experimentation with Cosmacmicroprosessor. Nevertheless, the demand for Telmac was so extensive that he and his co-workers founded a manufacturing and marketing company. ${ }^{14}$

Telmac was the most popular microcomputer in Finland in late 1970s. Computer hobbyists were particularly keen to buy the Telmac assembly kit as their first microcomputer. Approximately 2000 units were sold in four years and according to some statistics, the market share of Telmac was about $60-70$ percent. $^{15}$ Simultaneously, demand for kit computers increased as schools and other institutions providing education in data processing needed suitable, cheap microcomputers. The most important kit computers produced by educational institutes of data processing and/or electronics were TAM (Tampere University of Technology), Innocomp (Helsinki University of Technology), and Ninekit (Helsinki Polytechnic). ${ }^{16}$

13

14 Telmacin synty, Osmo Kainulainen, Tieturi 3/1983, 8-9.

15 Mikrouutisia läheltä ja kaukaa, Vesa Valtonen, Prosessori 1/1979, 18.

16 For more information, see some Finnish articles. Oma tietokone jokaiselle kurssilaiselle, Prosessori 1/1979, 7, Huippunopea ohjelmointijärjestelmä Z80-mikroille - ZBASIC, Timo Koivunen, Prosessori 6-7/1980, 54-55, Ninekit - vahva kotimainen harrastajamikro, Johan Helsingius, Prosessori 12/1981, 75. 


\section{THE COMPUTER CLUB ACTIVITY OF TELMAC USERS}

For beginners, assembling a kit computer was a difficult task. The range of use for kit computers was also very limited. Computer hobbyists were pleased if they managed to turn a microcomputer on. This was quite general problem caused by the lack of knowledge and education. For the average computer hobbyist, the foundation of a computer club offered the easiest solution. Therefore, the popularity of Telmac-computer clubs was high especially in the late 1970s and the early 1980s. Osmo Kainulainen founded the 1800 Users' Club Association, the biggest Telmac computer club, in the spring of 1978. This club was mainly a national support association for all Telmac users, ${ }^{17}$ consisting of some 450 members in 1980. The 1800 Users' Club Association was not considered as a marketing channel for Telmac and Osmo Kainulainen had no official status in club. ${ }^{18}$

The 1800 Users' Club Association worked actively during the late 1970 s and the early 1980 s, the forms of activity included assembling computer equipment, programming and general studying of computer technology. Moreover, many Telmac-users provided useful knowledge on computer science and electronics. In addition, the clubs provided possibilities for program exchange and equipment supply. The club published its own magazine called Tieturi, where for example, the published instruction plans for different kinds of circuit boards, converters and other peripheral devices. Different kinds of programming tips accompanied these plans. Members also organised meetings between Telmac-hobbyists. ${ }^{19}$

With the growing popularity of Telmac-microcomputers, some other computer clubs were also born in late 1970s. For instance, MikrofanComputer Club Association of Pirkanmaa, founded in 1979, and is still running today. The most important goals and plans for this club were defined as "watching the development of microcomputer field, providing educational courses for programming and electronics, and supporting equipment trade". It is noteworthy that in planning their club activity, Mikrofan had same kinds of principles as the 1800 Users' Club Association. In addition, local identity was of course an important

17 Telmacin synty, Osmo Kainulainen, Tieturi 3/1983, 11.

18 Vilkas toimintavuosi 1800 Users' Clubilla, Prosessori 3/1980, 34-35.

19 For articles, see Analogi-digitaalimuunnin ADC 0809 -piiristä, Hannu Pulkkinen, Tieturi 4/1982, 9-13, Epromin (2716) ohjelmointi Sairasen muistikortille, Pertti Juvonen, Tieturi 5/1982, 12-17, Kerhokoneen käyttöjärjestelmä, Heikki Levanto, Tieturi 1/1983, 8-11, Seikkailu muistiavaruudessa, Pertti Juvonen, Tieturi 4/1983, 18-22. 
driving force. Almost all of the members came from the city of Tampere and its environs. ${ }^{20}$

Assembling peripheral devices was popular, presumably due to the limited availability of devices and the high price levels. Computer clubs also aimed to create devices for commercial purposes. The members built different kinds of professional devices, some of which were quite impressive. For example, in the early 1980s, Mikrofan constructed a LED-panel for the Tampere Theatre; the size was 7 meters wide and 2 meters high. A Commodore 64 home computer operated this advertisement panel and it was in use until 1999. ${ }^{21}$

Experimental activity also had its less serious side. This was particularly evident when Telmac-users "played" with their machines and, as a result, created fun, playful inventions. The miniature railways operated by microprocessors offer a good example. ${ }^{22}$ Interestingly, miniature railways were popular among electronic hobbyists and early computer hackers. ${ }^{23}$ Similar features characterised software creation too. Hobbyists programmed not only applications but computer games too. However, the status of entertainment software was always ambivalent, a point worth of further attention. Computer gaming was often regarded as a childish hobby and the programming of games as an activity for the younger generation. On the other hand, games and the playful use of computers also served useful purposes. For instance, members of the 1800 Users' Club Association willingly admitted that in the beginning, computer hobbyists were always "just playing". ${ }^{24}$

Electronic hobbyists and radio amateurs were among the first to take up microcomputers as a hobby. Consequently, quite many of the founding members of computer clubs had also been members in electronics clubs and associations of radio amateurs. Some of the computer hobbyist also had a professional background, which explains why the average age of a typical computer hobbyist was well above 20 years. There are several remarkable similarities between the hobby users of early microcomputers and those of electronics and radio technology. For example, the interaction between work and hobby, the importance of clubs and associations, and the experimental ways of dealing with new

20 Kokouskutsu. Perustavan kokouksen jatkokokous. Mikrofan 20 vuotta ("Mikrofan 20 years") -CD-ROM, Mikrofanin piirissä jo 100 nuorta. Innostus riittää mikrokerhon jäsenyyteen, Mikko Hamunen, Tietoviikko 17.11.1983.

21 Pekka Ritamäki, interview December 13. 2001.

22 See, for example, instructions for building such kinds of miniature railways. Pienoisrautatie ja 1802, Hannu Peiponen, Tieturi 5/1982, 18-21.

23 Levy 1994, 17-38.

24 These are Pekka Ritamäki interview December 13. 2001. Vuoden vaihtuessa, Lauri Levanto, Tieturi 1/1983, 7. 
technology form similarities. In addition, these actors also shared the solid community spirit between the hobbyist and general "pioneer spirit". There was also tendency to regard these hobbies as an adventurous, masculine free time activity. ${ }^{25}$

When new, inexpensive 8-bit serial produced home computers like Vic-20, Commodore 64, and Sinclair Spectrum came onto to market in the early 1980 s, the popularity of kit computers in computer clubs began to decrease. The marketing of IBM PCs started in 1983 and strengthened belief in the success of commercial produced microcomputers. At the same time, microcomputers guided youngsters into the future of information society. The latter idea was based mainly on the popular discourse, but it was also backed by the Finnish government's well-known plan for an information society. ${ }^{26}$ Of course, other factors also influenced the microcomputers first major breakthrough onto the consumer markets, economic reasons are amongst the most important. In 1982-1984, Finland's economy was booming and families had extra money to spend. Consequently, the sale of consumer electronics increased substantially. Families bought, for example, video recorders, and extra televisions and, for the first time, microcomputers. ${ }^{27}$

The new home computers and the whole expansion of the computer markets created a younger "home computer generation". The hobby of working with home computers established and continued old masculine habits and traditions of technologically oriented hobbies. Computer games and programming became popular especially among the young men and boys. ${ }^{28}$ The importance of home computers began to gain recognition when new clubs and associations were founded. Again, professionals and students of data processing and electronics had some role in establishing these new clubs. In addition, youth workers, teachers, and other people interested in association activity established more and more computer clubs.

Courses on microcomputers started to become more common, which stimulated the activity of more professionally oriented computer clubs. In many cases, the assembling of kit computers, electronics, and peripheral devices was thus considered an activity defined by professionals and experts largely than before. Some suggested reasons for this are as follows. through writings published in popular computer magazines such as Prosessori and Tietokone which has been mentioned above and in popular technical magazines such as Tekniikan Maailma.

27

28 
1. The price level of serial produced microcomputers came down.

2. The construction of microcomputers became increasingly complicated.

3. Programming and using the new applications became more rewarding for the users.

This also presented certain problems and challenges for the older computer clubs. For example, in the early 1980s some members of the 1800 Users' Club Association still believed that there was a future in the teaching of computer electronics. For example, Reijo Toivanen-the chief editor of Tieturi club magazine-noticed already in 1982 that "nowadays commercial manufacturing of kit computers has virtually ceased. This kind of independent activity is almost the only way to encourage new hobbyists who are interested in kit computers and electronics". ${ }^{29}$ The 1800 Users' Club Association was still functioning in the late 1980s, but after this time, there was no sign of activity. ${ }^{30}$ Some computer clubs solved the problem by making reforms in their way of acting. Mikrofan, for instance, started to use serial produced microcomputers and consequently programming applications gained more popularity. ${ }^{31}$

\section{INTERACTIONS BETWEEN PAID WORK AND PRIVATE HOBBIES}

Expertise gained in computer clubs could be usefulin working life. The interaction between paid work and private hobbies was more obvious in computer clubs established in electronics industry. The Microprosessor Club of Salora Ltd is a good example. ${ }^{32}$ Salora Ltd was the largest manufacturer of television sets in Scandinavia. The use of microprocessors in television sets grew steadily in the 1970 s. $^{33}$ Competition in the television industry, the rapid development of microprocessors and the lack of education were the main reasons for the foundation of this particular computer club in $1979 .{ }^{34}$ According to Petri Paju, in the Finnish electronics industry, the linkage between work and hobby had a strong connection to production values and culture-this

29

30

31

32

33 Åke Nyholm interview October 20. 2000. See also, Mikroprosessori televisiossa, Pekka Valjus, Prosessori 6-7/1980, 8-10.

34 Mikroprosessorikerho Salora Oy:ssä, Jorma Lindell, Papers of the Microprosessor Club of Salora Ltd 27.12.1982, 1-2. 
view was particularly pointed out by the engineers of Salora Ltd. ${ }^{35}$ Once again, most of the members - usually electronics engineers - had earlier been interested in radio amateur activity and electronic hobbies. ${ }^{36}$ When members were making plans for club activity, they presented an idea that club could provide some basic education on microcomputing for the other workers in Salora Ltd. To support the plan, the computer club arranged some evening courses in Basic-programming and application management. ${ }^{37}$

For the Salora company, the microcomputer hobby was of course a useful activity and worth supporting. Club members could arrange their own microcomputer education and create some new applications and equipments, which could not be created and tested during working hours. ${ }^{38}$ The computer club had the indirect impact of creating the necessary expertise for educating company engineers on the latest information technology. Demand for this kind of activity decreased during the 1980 s due to increasing education on microcomputing in schools and universities.

\section{CONCLUSION: THE MICROCOMPUTER HOBBYISTS AS PLAYERS AND INVENTORS}

Microcomputer hobbies as a whole were clearly a major stimulator for personal computing. The major conclusion to be drawn from this study is that computer club activity was actually a continuation of the old social and cultural features of technically oriented hobbies. Electronic hobbies and radio amateur activity played a decisive role in this development. It is also important to notice that association activity had influential traditions in Finland.

We can view the early microcomputer hobby and club activity as side product of research work dealing with microprocessor technology. All three computer clubs mentioned here had this kind of connection. A particularly strong interaction between work and hobby was established in The Microprocessor Club of Salora Ltd. One can say that, for the engineers of Salora Ltd, work was actually a well-developed hobby. We can see the advancements in microcomputer technology as a major reason why this kind of activity changed during 1980 s. We can say that work, education, and hobby were all blended together. Computer hobbyists

\footnotetext{
Paju 2003.

36 Jouko Happonen and Arto Vihtosen men's interview December 19. 2000.

${ }^{37}$ Mikrokerhon historia, Jorma Lindell, Papers of the Microprosessor Club of Salora Ltd 30.12.1988, 2.

38 Jouko Happonen, Arto Vihtosen interview December 19. 2000.
} 
engaged in computer hobby thereby playing a key role in the first users' exploration of the possibilities of microcomputers. The history of these computer clubs also gives us a clear vision of how the research work and hobby use of microcomputers altered during the 1970s and the 1980s.

\section{SOURCES}

\section{Archive sources}

Papers of the Microprosessor Club of Salora Ltd. Collected by Jorma Lindell 31.12.1988. Electronic Museum of Salo -project collections

Interviews (Collected by Petri Saarikoski and Jaakko Suominen)

Åke Nyholm 20.10.2000 (Nokia Display Products, Salo)

Jouko Happonen, Arto Vihtonen 19.12.2000 (Nokia Display Products, Salo)

Pekka Ritamäki 13.12.2001 (Mikrofan, Tampere)

\section{Literature}

Bell, Clas von, LINTURI, Risto, TALA, Martti. Mikrojen 20-vuotta. ("The First 20 years of Microcomputers") Mikrotietokone Suomessa 1973-1993 ("Microcomputers in Finland 1973-1993") (9-34).Risto Linturi, Martti Tala (eds.). Yritysmikrot Oy: Helsinki 1993.

Boddy, William. Elektrovisio: Sukupuita ja sukupuolia. ("Archaeologies of Electronic Vision and the Gendered Spectator") Sähköiho, konelmedialruumis (53-82). Erkki Huhtamo, Martti Lehti (eds.). Vastapaino: Tampere 1995.

Campbell-Kelly, Martin, Aspray, William. Computer. A History of the Information Machine. Basic Books: New York 1996.

Ceruzzi, Paul E.. A History of Modern Computing. The MIT Press: Cambridge, London 2000

Freiberger, Paul, Swaine, Michael. Fire in the Valley. The Making of the Personal Computer. McGraw-Hill: New York 2000 (1984).

Håpnes, Tove. Not in Their Machines: How Hackers Transform Computers into Subcultural Artefacts. Making Technology Our Own? Domesticating Technology into Everyday Life (121-150). Merete Lie, Knut H. Sørensen (eds.). Scandinavian University Press Oslo 1996.

Jokela, Esko, Korkala, Jussi, Sarso, Pekka. Tietojenkäsittelyoppi. Osa 1. Laitteisto ("The Basics of Data Processing, Part 1: Hardware"). Tampere 1972.

Levy, Stephen. Hackers. Heroes of the Computer Revolution. Penguin Books New York 1994 (1984).

Nissen, Jörgen. Pojkarna vid Datorn. Unga entusiaster i Datateknikens värld. ("Boys in front of Computers. Young Enthusiasts in the World of Computer Technology"). Linköping Studies in Arts and Science no. 89. Department of Technology and Social Change. University of Linköping 1993.

Paju, Petri. Huvia hyödyn avuksi jo 1950-luvulla. Nim-pelin rakentaminen ja käyttö Suomessa. ("Interactions between work and entertainment in the 1950s. The Construction and usage of the Nim-game in Finland") Wider Screen 2-3/2003. http://www.film-oholic.com/widerscreen/. 11.9.2003.

Pantzar, Mika. Tulevaisuuden koti: arjen tarpeita keksimässä. ("The Home of the Future. Domestication of Everyday Life") Otava: Helsinki 2000. 
Saarikoski, Petri. Pioneerien leluista kulutuselektroniikaksi. Suomalainen kotimikroharrastus tietotekniikan murroksessa 1980-luvun alusta 1990-luvun puoliväliin. ("From the Toys of Pioneers to Consumer Electronics. The Cultural History of Home Computing as Hobby in Finland from the 1980s to 1990s.") Licentiate thesis, General History, University of Turku. Turku 2001.

Saarikoski, Petri. Juottelua ja heksakoodia. Kerhotoiminnan asema ja merkitys suomalaisen mikrotietokoneharrastuksen varhaiskaudella. ("Solder alloy and Hexadecimal code. The History of Finnish computer club activity in the early phases of microcomputing"). Tekniikan Waiheita 3/2003. Finnish Society for the History of Technology. 2002.

Salmi, Hannu. "Atoomipommilla kuuhun!" Tekniikan mentaalihistoriaa. ("The History of Mentality and Technology") Helsinki 1996. Edita: Helsinki 1996.

Spigel, Lynn. Make Room for TV. Television and the Family Ideal in Postwar America. University of Chicago Press: Chicago 1992.

Suominen, Jaakko. Sähköaivot sinuiksi, tietokone tutuksi. Tietotekniikan kulttuurihistoriaa. ("Getting Familiar with the Electric Brain, getting to know the Computer") Research Centre for Contemporary Culture, publication no. 67. University of Jyväskylä. Jyväskylä 2000.

Wiio, Osmo A. Mikrotietokoneet. ("Microcomputers") Mikrotietokone Suomessa 1973-1993 ("Microcomputers in Finland 1973-1993") (152-158). Martti Tienari. Suomen Atkkustannus: Helsinki, Jyväskylä 1993.

\section{Maganizes}

IBM Katsaus 2/1965.

Prosessori 1/1979, 3/1980, 6-7/1980, 12/1981.

Tieturi 4/1982, 5/1982, 1/1983, 3/1983, 4/1983.

Tietoviikko 17.11.1983.

MikroBitti 8/1988.

\section{CD-ROMs}

Pirkanmaan mikrotietokone Mikrofan 20 vuotta ("Mikrofan - Microcomputer Club of Pirkanmaa, 20 years of activity") -CD-ROM. 